\title{
The ASSESSMENT AND ReVIEW OF THE CitizenshiP CRITERION AND ITS DISTINCTION FROM OTHER SIMILAR CONCEPTS IN IRANIAN LAW
}

LA EVALUACIÓN Y REVISIÓN DEL CRITERIO DE CIUDADANÍA Y SU DISTINCIÓN DE OTROS CONCEPTOS SIMILARES EN LA LEGISLACIÓN IRANÍ

Abbas Zera'at ${ }^{*}$

Meysam Nematollahi**

\begin{abstract}
Citizenship is one of the concepts discussed in most fields of humanities. Each field has studied it within a context regarding its perspective. The criterion of citizenship has been neglected in most of these studies and has received less attention. Who are the subjects of this word? This argument is necessary because words have their own effects and cases in the law; therefore, it is necessary to determine the subject before the other rights and duties are considered. Similarly, the present research is an attempt to find out what people are subject to citizenship. By considering the existing rules of the law, it can be seen that issues such as nationality and residence are older than "citizenship". However, none of these issues can be a criterion for citizenship. Even the subject of human legal documents cannot be dealt with as a criterion of citizenship because the acceptance of each criterion has some challenges. What is certain is that being a citizen is itself a factor for citizenship and should be considered as a condition for citizenship according to its components.
\end{abstract}

Keywords: Citizen, Human Rights, Citizenship, Iranian Law, Constitutional Rights

\footnotetext{
* Faculty member at Kashan University (Esfahan, Iran). zeraat@acu.ir

** Ph.D. candidate of Criminal Law and Criminology, at Kashan University (Esfahan, Iran). n.maysam@yahoo.com
} 
Resumen: El concepto de "ciudadanía" es un concepto discutido en la mayoría de los campos de las humanidades. Cada campo lo ha estudiado dentro de un contexto, desde su perspectiva. Pero el criterio de ciudadanía ha sido descuidado en la mayoría de estos estudios y ha recibido menos atención. ¿Quiénes son los sujetos ciudadanos? Es necesario entrar a este argumento porque las palabras están diseñadas para tener sus propios efectos en el derecho; es necesario delimitar el tema antes de considerar los demás derechos y deberes. La presente investigación también busca averiguar qué personas están sujetas a la ciudadanía. Al considerar las reglas de la ley existentes, se puede ver que cuestiones como la nacionalidad y la residencia son más antiguas que la "ciudadanía”. Sin embargo, nada de esto sirve como criterio para la ciudadanía. Ni siquiera el tema de presentar documentos legales puede considerarse como un criterio de ciudadanía, por la especificidad del criterio. Lo cierto es que "ser ciudadano" en sí mismo es un factor de ciudadanía, y por ello debe considerarse como una condición para la ciudadanía según sus componentes.

Palabras clave: Ciudadano, derechos humanos, ciudadanía, ley iraní, derechos constitucionales

Sumary. I. Introduction. II. The evaluation and investigation of the concepts of nationality. II.1. Nationality background. II.2. Definition of nationality. II.3. The tenets of nationality. II.3.1. The existence of the state. II.3.2. The individual. III. The challenges of nationality as the citizenship factor. III.1. Granting nationality. III.2. Individuals with dual and multiple citizenships. III.3. Exclusion. III.3.1. Formal exclusion. III.3.2. De facto exclusion. IV. Human rights as the criteria for citizenship. IV.1. The differentiation of human rights and citizenship. IV.2. The relationship between the rights of citizenship and human rights. V. Conclusion. References.

\section{INTRODUCTION}

The term "citizenship" is a novel term the Iranian literature, so that even its cases and examples have not been yet defined. This term does not have a long history in the political and legal literature in Iran. It has been presented for less than a decade in the country's legal rhetoric and particularly in its current laws. The law established this term with much delay. However, it soon found its place and became central to most of the discourses including the legislative, judicial, and even executive debates. 
The term "citizen" is one of the concepts used in the various fields of humanities including political sciences, sociology, and law. Nonetheless, in each of these disciplines, this term has the appropriate semantic meaning in accordance with that discipline. As citizenship is the subject of many studies and laws, it is necessary to review its quality. The field of law particularly studies the individuals considered as citizens with duties and rights based on rules and regulations. For the same reason, we examine the citizenship criterion in this article. In other words, this article will attempt to provide a precise condition for citizenship as a matter of rights and duties in society.

Before getting into the details of the discussion on the importance of this topic (i.e., the criterion of citizenship), it should be noted that the person addressed by these documents is still unknown in the present discourses. This is because the provision of any measure for citizenship can have its own cases and examples despite the ratification of various documents on citizenship (Sarvari Moghadam, 2004, p. 1).

This discussion becomes essential as some countries have divided their residents into two, three and sometimes four classes and have chosen a specific but largely vague "term" to refer to each class. On the contrary, the cases of each term are somewhat uncertain in international documents related to these concepts. A case in point is the 1981 Algeria Declaration between Iran and the United States ${ }^{1}$ in which the meaning of citizens and nationals must be fully understood. The importance of the issue is such that "citizen" is not a legal title in Iran according to some people and there is no one who is considered an Iranian national with this title (Abdul Ghani Vastani, 1984, p. 32). Hence, it is important to identify the subject in the beginning of the discussion.

\section{THE EVALUATION AND INVESTIGATION OF THE CONCEPTS OF NATIONALITY}

\section{II.1. Nationality background}

The origin of citizenship dates back to the establishment of borders and political divisions on Earth. It is also related to the existence of numerous independent states on either sides of these borders. This is the origin of the emergence of international law. The discussion on the relation and dependence of individuals on states would not make any sense with the existence of only one state. Although the current rules about nationality have

\footnotetext{
${ }^{1}$ Article 7 of Algeria Declaration states that «the Iranian and American nationals are defined as legal persons who are citizens of Iran or the United States».
} 
been created over the last two centuries, the relationship between the individual and the state is an old problem. This relationship has existed ever since the states emerged in their most basic form (Seljuki, 1991, p. 55).

In sum, the issues of citizenship and the geographical divisions have been discussed since the emergence of the first state. These issues have divided the individuals and the population of countries into insiders and outsiders. However, the criterion for recognizing these two items is not clear. When the state was merely recognized by the king, the obedience in response to his commands was the leading factor connecting the individual to the state, and this obedience determined a person's nationality. On the other hand, when religion was the main reason for the emergence of a state, the main determinant for nationality was to follow the official and dominant religion. Following the dominant and official religion has often been the criterion for dividing individuals into citizens and non-citizens. The question of religion was a stronger criterion for defining citizenship than any other (Daneshpezhooh, 2011, p. 26).

\section{II.2. Definition of nationality}

Typically, the term "nationality" and "citizenship" are used to identify individuals in domestic and international law. In principle, nationality is based on the relations between a particular person and a state, whilst "citizenship" is based on the relation between a person's particular circumstances and a land or place of residence (Sarvari Moghaddam, 2004, p. 4).

The word "citizen" has been dealt with frequently in Iran's laws in such a way that the legislator has dedicated the second book of the second volume to the issue of nationality in the civil law. However, the legislator has never defined the term. Only the conditions required for citizenship, nationality or abandoning one's nationality have been discussed in articles 976 to 991 of this law. Thus, nationality lacks a legal definition and it is only in this regard that we may refer to definitions provided by the doctrine and law scholars. In the definition of nationality, a person belongs legally to the population of the state. In this definition, the legal sense of belonging is the factor for defining nationality, although nationality also includes legal and spiritual relations in addition to the legal association (Vallagard, 1981, p. 59).

Hence, the legal, political, and spiritual relationship between a person and a certain state is taken for granted in the nationality. Moreover, individual rights and duties derive from that relationship (Ebrahimi, 2004: 84). In this definition, all the aspects of citizenship have been addressed. 
It needs to be explained that the term "nationality" is equivalent to the French word nationalite translated as "nationality". However, citizenship differs from nationality. What is meant by a nation is "all the people inhabiting a land". In other words, nationality and citizenship both express the status of individuals in terms of belonging to a nation. However, the legal relationship of one person with the nation is addressed in describing the nationality while the true and spiritual connection is discussed in the case of citizenship. Of course, nationality is accorded to the individual by the state and not by the nation, and the state is the legal entity representing a group of persons in international law (Al Kajbaf, 2010, p. 18).

\section{II.3. The tenets of nationality}

Based on the definitions provided for nationality, we need to have two tenets for nationality: The first case is the state that grants this status, and the second case is the person who becomes a citizen of the state. We will examine each case in what follows.

\section{II.3.1. The existence of the state}

The first condition for the acquisition of nationality is the creation of a state in such a way that nationality is conceived within a state and country. In this case, if a person is in a region without a state or sovereignty, no such thing as nationality will be understood in its basic sense.

However, the state should have three elements: population, territory and political power, in order to have legal personality in public and international laws and provide its citizens with a nationality. On the contrary, the nationality of the residents of a state which lacks political power or is regarded as the colony of another government is measured in terms of the new state. The term used for the main residents and the residents of the occupied territory is often different. For instance, the French use the term "citizen" (eitagem) for the citizens of France and use the term "subjects" for the people of the colonies. They use the word ressortissant as a general term to include both of them.

In case of protectorates, the protecting state only controls some of the affairs under the contract known as protectionism while the protectorate defends its autonomy on other aspects. The relationship between the people's nationality and the protected government still exists, even though the political support is given by the protecting state (Poornemati Shamsabad, 2012, p. 20).

In this regard, Article 41 of the Iranian Constitution stipulates: «The citizenship of Iran is the absolute right of every Iranian national, and the 
government cannot deprive any Iranian of his or her nationality except upon his own request or when he becomes a citizen of another country».

Article 15 of the Human Rights Declaration in 1987 also stipulates that «everyone has the right to enjoy the status of citizenship (nationality). People cannot be arbitrarily deprived of their nationality or be denied the right to change their nationality». The state can identify some individuals as their nationals or deny the citizenship to others according to the constitution and international documents.

\section{II.3.2. The individual}

Each state consists of a community of individuals and applies a relationship between the individual and the society. Its laws apply for those who are its citizens and its true members (Von Golan, 1999, p. 192).

In relation to individuals, nationality expresses how a person is related to a particular state. In this way, the legal connection of the people with a particular state is based on a human relationship. This is because the state determines who are considered their nationals according to their own laws (Maryam, 1987, p. 22).

On the international scale, however, it should be noted that individuals are not regarded as the main and basic entity, as is the state. Rather, the individuals have some protective rights in domestic laws. Nevertheless, the ultimate target of domestic or international law has always been humans and individuals.

\section{THE CHALLENGES OF NATIONALITY AS THE CITIZENSHIP FACTOR}

With respect to the definition and tenets of nationality, it should be said that if nationality is introduced as the factor of citizenship, there will always exist some challenges that cannot be explained by the criterion of nationality. The status of such challenges will remain disputable.

\section{III.1. Granting nationality}

As discussed earlier on the subject of nationality, in order for a citizen to be considered a national of a certain country, we need a state to grant citizenship to that person. In other words, there is no possibility for an individual to be regarded as a citizen without the state and its recognition.

However, the notion of citizenship is bound to the notion of nationality. In the relevant literature, some issues of citizenship are 
sometimes coupled with the issues of nationality in constitutional law, international law and human rights. Of course, this does not mean that the two concepts are totally in accord. Perhaps, the definition of both items that is based on the sense of belonging to a political society has led to this convergence because we see a form of belonging to a political and civil society in the definition of citizenship and nationality. At the same time, the point that separates citizenship from nationality is the subject of human rights. Human rights are indeed the boundary between citizenship and pure nationality. Then, those to whom the concept of nationality fully applies in the international and domestic law might have a nationality. However, they lack citizenship rights and they cannot be regarded as citizens. The classic and popular concept of nationality that is raised in domestic and international law cannot convey the components of citizenship. Therefore, we must pay attention to the concept of citizenship to complete the subject in terms of human rights. On the other hand, nationality usually involves the external and international aspect while citizenship includes the national and domestic aspects of membership.

In the United States of America, a citizen, who is considered to be different from a national, is a subject who has full civil and political rights. In addition to be a citizen, a national has a permanent loyalty to the country (Seyyed Fatemi, 2007, p. 3).

One of the most important contradictions in citizenship lies in the concept of "granting citizenship". It refers to the administrative practice in English, French and some other European languages and is used when turning a foreigner into a citizen. Granting citizenship involves the recognition of membership in a particular state or nation based on "natural laws", which are also related to the natural environment and ethnicity. Foreigners are only "naturalized" after a long process (which in most countries ranges between 2 and 17 years). This can be taken as a compensation for an exception to the usual "lifelong membership" principle (Castells \& Davidson, 2003, p. 67).

In this regard, Faro Heller notes that being accepted as a citizen has nothing to do with nationality; rather, it is based on the process of cultural adaptation. In this regard, the most appropriate term to highlight citizenship is "cultural development". However, granting citizenship can refer to the assimilation in the order considered as "the only type of natural order". Accordingly, failure in homogeneity for migrants can lead to some consequences such as being considered a deviant person or an alien. The conflict between nature and culture has always been seen in the discourses of citizenship, state and nation. The concept of granting citizenship is clearly in conflict with the view of citizenship that recognizes the cultural neutrality 
and its freedom for all members of society. Interestingly, in the Germanspeaking countries where very restricted citizenship-related policies are adopted, the relatively neutral term einburgrang that means naturalization is employed (Castells \& Davidson, 2003, p. 71).

\section{III.2. Individuals with dual and multiple citizenships}

If citizenship is one of the requirements of the international order for all people, the same order establishes that each person has the sole nationality of one state because having more nationalities causes more duties for a person in relation to all the states of which he is a national. This might be difficult at times, and might create conflict between the respective states. The respective state cannot support a subject politically in response to other states (Ghasemi Shub, 2004, p. 15).

Some measures have been taken to address the issue of dual citizenship on an international scale. In dual citizenship cases, we can refer to The Hague Convention on the Conflict of Citizenship approved on April 12, 1930. According to Article 6 of the Convention, «a person having two nationalities of his own volition can give up one of his two nationalities without undermining the freedom of one state and with the permission of the state he or she wishes to abandon».

Despite international efforts to reduce the addition of citizenship, this situation has continued so far and is generally accepted by international documents as Article 3 of the Convention states that «with the observance of the provisions of the present convention, a person of two or more nationalities shall be deemed as a national of all of those countries».

Although dual citizenship has been accepted, the issue of nationality cannot be regarded as a factor for citizenship due to multiple citizenships. With the acquisition of citizenship by the state, those newly recognized as citizens are deprived of some civil rights such as the right to vote or hold some offices.

\section{III.3. Exclusion}

One of the challenges in accepting citizenship as its underlying factor is the exclusion. In this sense, the citizenship of some people means that some others should not have citizenship. In the Greek city-states slaves, foreigners, and, above all, women were deprived of citizenship. It should be said that the issue of exclusion takes place today as formal and de facto exclusion.

Historically, the concept of citizenship depends on the exclusion of non-citizens. Thus, the groups that are not part of the community are 
excluded or marginalized. According to the nationalist and traditionalist views, citizenship involves receiving the passport of the place of residence. Nevertheless, some of the advocates of this classical view admit that another principle is growing along with the principle of soil and blood. This new principle, called the principle of "residence", has gained enormous relevance. According to the rule of residence, people can earn a citizen's right by staying in a country. Nevertheless, despite the fact that the principle of residence attributes many rights to permanent residents such as the right to work, the right to benefit from social security and health services, the right to safety guarantees, the right to access to education, and the right to protection against compulsory return, individuals benefited from this principle are not regarded as citizens, but rather as pseudo-citizens (Castells $\&$ Davidson, 2003, p. 189). The difference between a citizen and a pseudocitizen is the fact that the pseudo-citizen is not entitled to political rights and does not receive the whole gamut of social rights.

\section{III.3.1. Formal exclusion}

Today, the formal exclusion of citizenship applies most of all to immigrants. By 1995, the total foreign population in the countries which were the members of the Organization for European Development and Cooperation was 19.4 million, of which only 6.7 million were citizens of the European Union. Of this population, 2 million were from North Africa, 2.6 million were from Turkey, and 1.4 million were from former Yugoslavia. The vast majority of these immigrants were actually born in the countries that were their place of residence, but they were deprived of citizenship because of the "blood principle" (i.e. citizenship due to relation or ius solis). Even in Australia and North America, which make access to citizenship easier, there are many non-citizen residents. These people belong to society as workers, taxpayers and parents, but their full political participation is denied. Illegal immigrants may even have long periods of residence while they do not have many of the basic rights. This issue violates the principle of liberal democracy that considers all members of the society as citizens (Castells \& Davidson, 2003, p. 58).

\section{III.3.2. De facto exclusion}

Another aspect of this problem is de facto exclusion. This exclusion means that there are important groups that are often deprived of full political participation as a citizen in many countries by virtue of such criteria as race, ethnicity or indigenousness. Because of this social, economic, and cultural exclusion, they are deprived of any chance of having political representation 
and the right to make any real comments about the decisions that affect their lives. This situation itself is partly reflective of the fact that the implied meaning of citizenship in contemporary history has been developed through the attachment of social rights to civil and political rights. In other words, a certain level of economic and social well-being must be created before people can enjoy formal political rights (Mariega, 2012, p. 139).

\section{HUMAN RIGHTS AS THE CRITERIA FOR CITIZENSHIP}

It seems that the distinction between these two concepts is clear at the theoretical and academic levels. However, this distinction cannot be observed in the realm of practical requirements and the political discourse of society. Moreover, these concepts and values are sometimes distorted from their original position and find a different meaning that varies with the context. Citizenship and the human rights discourses have many links, even if their sources are different. Citizenship does not necessarily mean a normative system, because it has links with historical and social values and developments, while the values of human rights are universal. The relationship that creates citizenship is a mutual one based on rights and duties, whereas this relationship is one-sided and demand-oriented. Citizenship rights are a modern discourse about human rights that were raised for the first time in the Charter of Human Rights and the French Citizens. They have been expanded every day since then (Nasiri 2001, p. 26).

\section{IV.1. The differentiation of human rights and citizenship}

Modern citizenship rights are separate from human rights. This independence means that we must carefully define and describe this science, because its functions are different from human rights. Citizenship rights imply the relationship between urban residents and their relation to state agencies. In this regard, they should be generally considered as a specific interpretation of citizenship rights.

Civil rights define the relationship between the state and its citizens. Hence, civil rights affect the capacity of people's participation in the state. Moreover, the awareness of civil rights also affects the level of participation (Alawi, 2000, p. 50).

The two categories of civil rights and human rights refer to two different areas of human rights. What distinguishes human rights from the rights of the citizen is its territoriality. The scope of civil rights territory 
might include more than one country. A case in point is the citizens of the European cities or the commonwealth nations. That being said, civil rights are limited, unlike human rights that encompass all humans regardless of race, nationality, religion, and language. These rights are meaningful only in a person's relation with the state and the political community (i.e. the state, city, government or country) while human rights are universal and fundamental rights (Ardebili, 2007, p. 30).

Human rights transcend time and place. This means that we require no specific location for the inclusion of human rights. As a fundamental human right, the right to life is not bound to a certain language or a specific location; rather, it must be recognized everywhere. On the other hand, the right to be selected as a citizen might be restricted to a specific organizational location.

As regards the distinction between human rights and citizenship, a lawyer states:

«Human rights are those rights that each human being enjoys on the simple basis that he is a human. This category of human rights can be individual, collective, generational and universal. This is not necessarily related to the status of the individual and any particular time and place as these rights might be enhanced with the development of human societies. They might evolve through the economic, political, social and civic stages and encapsulate a series of other rights focusing on the existence of human beings. These include the rights of solidarity, the global and environmental rights, and the like. These are not necessarily controlled by a particular generation of human beings and include the rights for future generations as well. Today's human rights emerging in the form of charters and conventions have illustrated the rights of individuals regardless of the national concerns of state. Considering the internal requirements of any nation-state can bring about a deficiency in the scope of these rights in terms of quantity and quality. Citizenship rights arise when human rights are legalized and enforced within a civil society under a particular government» (Javad, 2007, p. 58).

In other words, the citizens' rights are related to that part of the public law and human rights that identifies and protects the political, social, cultural and economic rights of the citizens in terms of their political allegiance to their state. Human rights are founded on humans' intrinsic dignity. They belong to any individual, regardless of whether he lives in the community or in isolation. On the contrary, citizenship rights are those human rights which are determined by the life in a certain community. They can change according to the circumstances of societies and temporal and spatial conditions.

Human rights are the universal, intrinsic and inalienable rights that human beings must enjoy equally because of their humanity. They establish a normative process that regulates the mutual duties of individuals in 
carrying out some activities or refraining from practices as well as their relations with objects or positions within a normative and regulatory framework. Universality, inalienability, and being intrinsic, are the properties of the rights that human beings must enjoy equally based on their human dignity.

Universality means being beyond cultures, the intrinsic quality refers to human dignity, and being inalienable means that these rights are not rooted in the rule of law or the will of the state. It is clear that being inalienable does not mean that it is impossible under any circumstances to restrict some of these rights for legitimate reasons in dealing with certain individuals (Seyyed Fatemi, 2002, p. 6).

In sum, it can be stated that citizenship rights and human rights are different from the perspective of the holder, the person involved, and the subject. The recipient or the holder of the human rights is an entity that benefits from his membership in the human society as a member of the world, while the holder of the citizenship rights is a citizen in the sense that will be described. The human rights address any person, institution and community. These rights prescribe orders and recommendations while the rights of citizenship put the community or a certain individual within the bounds of a state or country.

The subjects of the concepts of the human rights are generally metaphysical. Thus, they are often generalized with some ambiguities. Nevertheless, citizenship rights are not ambiguous because they directly involve people and are executed in relation to people based on a legal basis.

Another view is based on the lack of unity between human rights and the rights of citizenship. In this regard, there is no significant difference between the two items and it seems that this view has been effective in Iranian laws.

Some other scholars believe that, although there is no general link between human rights and citizenship, they include some rights under the title of citizenship in many countries which have a judicial background. Hence, principle $32,33,35,37,38$ and 39 are the only principles of the Constitution that deal with the issue of civil rights. Despite the fact that in many cases the subject and content of the rights of citizenship and human rights may be the same - and it is very difficult to distinguish between them in this regard-what separates these two is that the rights of citizens are discussed within the framework of the state and nation. It is argued that a person has some rights for being the member and citizen of a political society. However, human rights are addressed on a global horizon regardless of any specific geographical area and membership in a political scale. 
Despite this conceptual difference, this separation is a very difficult task. The two concepts are intertwined in human rights declarations. As an example, the Universal Declaration of Human Rights stipulates:

«1) Everyone has the right to participate in the government of his country, either directly or through freely chosen representatives.

2) Everyone has the right to access public services in his own country.

3) The power of government is based on the will of the people. This will must be expressed in periodic and sound elections held by popular vote, equal to secret ballot or similar methods of free voting» (Art. 21).

Although the theme of this article is the rights of the citizen, and not human rights, the reason for bringing such an article and several other corresponding articles is that proper human rights can only be achieved through the acquisition of citizenship rights.

In sum, we can say that the relation between the rights associated with citizenship and human rights is public and private. Although civil rights and human rights are used interchangeably in many ways, many of the rights suggested in the Universal Declaration of Human Rights and the two related conventions are citizenship rights. Many of the rights concerning citizenship are rooted in human rights and some particular cases stem from the intrinsic dignity of human beings and human rights. These include the right to life (Article 3 of the Declaration), the prohibition of torture (Article 5), the ownership right (Article 17), the right to freedom of expression and belief (Article 19), the prohibition of imprisonment and arbitrary detention and exile (Article 9), mentioned in the Universal Declaration of Human Rights.

Nevertheless, there are some articles in the Universal Declaration of Rights and the two related conventions that do not seem to be derived from the intrinsic dignity of the human being. These are useful tools for the implementation and protection of citizenship rights, and are not human rights in the strict sense of the word. Some of these articles are: Article 8 on the effective right to refer to fair national courts, or Article 10 on the proceedings in independent and public courts, Article 20 on the freedom to form assemblies and peaceful populations, Article 21 on the right to have access to the public employment opportunities of the country and paragraph 3 of the same article about general elections with secret votes.

Many similar cases seem to be addressing civil rights rather than human rights despite being listed in the Universal Declaration of Human Rights. Furthermore, in the 1966 Covenant on Civil and Political Rights, articles such as Article 10 emphasize the separation of the defendants from convicts and Article 11 emphasizes the prohibition of the imprisonment of people for the lack of power to enforce contractual obligations. Meanwhile, 
Article 14 points to the right of the accused to ask the witnesses. It seems that these cases address the citizens' rights rather than human rights.

In contrast, there are cases that are common between human and civil rights. This means that they have originated from the intrinsic dignity of human beings and the fact that a person lives in a certain community. These cases can differ one society to another according to the circumstances of the society in which the person lives. A case in point is Article 12 of the Universal Declaration on Human Rights on the prohibition of interventions in one's private life, family affairs, place of residence, and communications. Paragraph 1 of Article 25 of the Universal Declaration discusses the level of livelihood, health and welfare of a person and his family and their support in the event of unemployment, sickness, physical disabilities, and injuries. Paragraph 2 of Article 25 is concerned with the right of mothers and children to have special benefits for healthcare, assistance, and social security and Article 24 points to the people's right to rest and have leisure time and reasonable work hours. Therefore, although human rights and citizenship belong to two different aspects of the rights of individuals, this does not separate them completely from one another and they are interconnected in many cases (Marie Guy, 2012, p. 62).

\section{IV.2. The relationship between the rights of citizenship and human rights}

In examining the concept and relation of the rights of citizenship and human rights, it is necessary to address the type of relationship between the people, the state and the nationality, and also the question of origin. Citizenship is the relationship between the individual and the state, in which the parties are committed with mutual rights and duties. Human rights are universal, fundamental and absolute rights. Universality means that all human beings enjoy these rights wherever they are regardless of their nationality, social status, and ethnic or racial origin.

Fundamentality refers to being inalienable. While these rights may be violated and neglected, the right of humans to enjoy these rights cannot be eliminated. Absoluteness means that these rights are the foundation of proper human life and cannot be conditioned or limited. Some scholars differentiate between human and civil rights and say that human rights are ethical principles that claim universal jurisdiction, whilst civil rights are linked to the freedoms and legal status bestowed to citizens in each particular society. However, it should be noted that civil rights and civil liberties are often based on the underlying and real beliefs of human rights. They are considered as ethical principles embodied in the concept of citizenship. Of course, human rights have found a pseudo-religious significance in some 
parts of the world and the idea of replacing religions with human rights can be criticized.

In order to conclude: firstly, as for the relationship between human rights and the citizen's rights, the latter is more dynamic, and has a longer history. Secondly, the citizen's rights are within the internal sphere of the country and relate to the person's relationship and citizenship in a territorial unit. In contrast, human rights have become the subject of international law and have grown due to the developments following World War II.

Citizenship rights are indeed considered the middle ground between the rights of the state and the rights of the community. In other words, human rights and citizenship rights converge when a conscious person intends to live with his compatriots in a peaceful society and promote his morals, reasoning, and conscience with an understanding of the "values" of human common life in an interactive environment. Human rights are the expression of this framework of the "value" and "excellence" that is undoubtedly strengthened by religious teachings. In this view, not only religion and human rights do not clash, but they also strengthen each other in some areas. In some other fields, each is used as a basis to include the other in the reality of social life. For example, the observance of human rights in the area of freedom of religion and practice establishes that the society and, in its more sophisticated view, the state should respect the basic human dignity that is related to such practices and rituals and should also avoid interference in such matters (Sharifi Tarazkouhi, 2012, p. 9).

According to some theorists, citizenship is a human right in a political society. Andrew Levine explains that sometimes certain political rights have been added to a particular right such as the right to the freedom of expression and assembly. Other similar cases include the right to vote, the right to fair treatment in judicial courts, and the right to travel and migrate. It is clear that these legal claims are considered the citizens' rights within in some cases. For instance, when we claim the right to vote, we receive a passport. If these rights are assumed as human rights, one can imagine that citizenship itself has been regarded as a human right. In this sense, citizenship is not freedom in the sense of being free to do what makes one happy; rather, it is a privilege associated with the benefits and duties that are appropriate for all people regardless of membership in a particular society. Probably, those who claim the human rights of this kind would like to determine these rights as a minimum of the most common forms of citizenship. On the other hand, the right to fair treatment in courts of law can be considered as a human right, while receiving the ordinary legal procedure, and the right to refuse to accuse oneself can be likely considered a legal right that is achieved after the membership in a particular political system (Levine, 2001, p. 171). 


\section{CONCLUSION}

1. The terms "citizens", "people" and "nation" were used synonymously in almost all modern forms of statements.

2. What should be noted in this regard is that the regime of equality in the rights imposed by revolutionary people regardless of the objective difference of a person would above all encompass the rights to guarantee "human dignity". Thus, in different texts of the declarations, we repeatedly encounter this kind of emphasis that everyone is in charge of his or her own life and property and has the right known as the freedom of speech, the right of awareness of what occurs in the political life, and the right of assembly, in order to take part in the discussions that lead to the creation of legislations.

3. Citizenship is a privilege and a right that is distinguished from other legal and political situations such as nationality or residence, because it includes certain specific privileges. Thus, although this term was initially considered synonymous with other similar terms, the affairs and requirements of cases such as nationality cannot be associated with it.

4. In addition to the legal and political constraints for the individual and the state, citizenship is a case followed by necessary participation in the management of society. Thus, being actively present in the management of the society distinguishes a citizen from the national and the resident. 


\section{REFERENCES}

Abdul Ghani Vastani, A. (2007). Study of Citizenship in Algeria Law. Legal Services Law Journal, 10(1), pp. 23-33.

Al Kajbaf, H. (2010). Citizenship in Iran and other countries. Tehran: Jangal Publishing.

Alawi, A. (2000). Investigating the Pattern of Citizen Participation in the Administration of City Affairs (Global and Iranian Experiences). Tehran: Publications of the Organization of Municipalities.

Ardebili, M.A. (2007). The reason and nature of citizenship rights from theory to law. Journal of Legal Justice, 58, pp. 131-152.

Castells, S. \& Davidson, A. (2003). Migration and Citizenship, translated by F. Taghilu. Tehran: Strategic Studies Institute Research.

Daneshpezhouh, M. (2011). Islamic Law and Private International Law. Qom: Publications of the Seminary Institute of Higher Education and University.

Ebrahimi, S.N. (2005). Private International Law. $4^{\text {th }}$ ed. Tehran: SAMT Publication.

Ghasemi Shub, A.A. (2004). A look at the status of foreigners in international law, with an emphasis on international human rights documents. International Law Journal, 31, pp. 86-93.

Javad, J. (2007). The reason and nature of the rights of citizenship from theory to law. Judicial Law Magazine, 58, pp. 103-129.

Levine, A. (2001). The Design and Criticism of Liberal Democracy Theory, translated by S.Z. Kalam. Tehran: SAMT Publication.

Marie Guy, A. (2012). Citizen in the History of Western Thought, translated by A. Bagheri. Tehran: Foroozan Rooz Publication.

Mariega, A. (2012). Citizenship at west thought. Tehran: Forozanfar publication.

Maryam, A. (1987). International Law. London: Pitman Publication.

Nasiri, M. (2001). Private International Law. Tehran: Aghah Publication.

Poorneamati Shamsabad, T. (2012). The concept of citizenship and its effects on jurisprudence. Najafabad: Islamic Azad University.

Sarvari Moghadam, M. (2004). A Review of the Difference of Nationality, Citizenship and Other Similar Terms in the Law of Iran, Britain, United States and France. Journal of the Teacher of Humanities, 1.

Seljuki, M. (1991). Private International Law. Tehran: Publications Office of International Law Services of the Islamic Republic of Iran.

Seyyed Fatemi, S.M.Q. (2002). Ethical and Argumentative Foundations of Human Rights. Journal of Legal Research, 35, pp. 45-62.

Seyyed Fatemi, S.M.Q. (2007). The reason and nature of citizenship rights from the theory to law. Journal of Legal Justice, 58, pp. 79-95. 
Sharifi Tarazkouhi, H. (2013). The Fields, Dimensions and Effects of Citizenship Rights. Tehran: Publications of Mizan Legal Foundation.

Vallagard, B. (1981). Special International Law, $2^{\text {nd }}$ ed. Tehran: Majd Publication.

Von Golan, G. (1999). An Introduction to General International Law, vol. I, translated by S.D. Aghaei. Tehran: Mizan Publishing. 